\title{
ERRATUM
}

\section{Erratum: A New Home for a Streetless Occupant: A Case Report}

International Journal of Clinical Pediatric Dentistry (2020): 10.5005/jp-journals-10005-1756

In the article titled "A New Home for a Streetless Occupant: A Case Report" published on pages 587-589, Volume 12 Issue 6 of International Journal of Clinical Pediatric Dentistry, ${ }^{1}$ the order of author was published incorrectly as "Ayush Pokhriyal, Preeti Dhawan, Shivangi Chandra, Avantika Tuli, Shalini Tomar", and it should be correctly read with the original author series as "Avantika Tuli, Preeti Dhawan, Shivangi Chandra, Ayush Pokhriyal, Shalini Tomar".

Accordingly, how to cite also would be read as: Avantika Tuli, Preeti Dhawan, Shivangi Chandra, et al. A New Home for a Streetless Occupant: A Case Report. Int J Clin Pediatr Dent 2019;12(6):587-589.

Also, Corresponding author for the article would be Avantika Tuli, Department of Pedodontics, Seema Dental College and Hospital, Rishikesh, Uttarakhand, India, Phone: +91 9634336684, e-mail: avantikatuli@gmail.com

\section{References}

1. Pokhriyal A, Dhawan P, Chandra S, et al. A new home for a streetless occupant: a case report. Int J Clin Pediatr Dent 2019;12(6):587-589. DOI: 10.5005/ jp-journals-10005-1639.

(c) The Author(s). 2020 Open Access This article is distributed under the terms of the Creative Commons Attribution 4.0 International License (https://creativecommons. org/licenses/by-nc/4.0/), which permits unrestricted use, distribution, and non-commercial reproduction in any medium, provided you give appropriate credit to the original author(s) and the source, provide a link to the Creative Commons license, and indicate if changes were made. The Creative Commons Public Domain Dedication waiver (http://creativecommons.org/publicdomain/zero/1.0/) applies to the data made available in this article, unless otherwise stated. 